\title{
Examination of the Risk of Injury to the Operating Room Staff and the Factors Affecting It
}

\author{
Jale Toptepe ${ }^{1}$, Yıldırım B. Gülhan ${ }^{2}$ and Halil Soyal ${ }^{2}$
}

\begin{abstract}
The operating room is a physical and functional environment in which surgical procedures are carried out, providing maximum comfort for the patient and the surgical team, which will expose the tissues to the minimum risk of infection during the operating. In terms of patients, each individual who will have operating constitutes a risk factor. In this study, it was aimed to learn the risks of injury and factors affecting the surgical instruments of health workers in the operating room Department of state hospitals that provide health services in Amasya province. A survey of 154 operating room personnel included in the scope of the survey was conducted with 33 questions including the individual characteristics of the operating room personnel and whether they were injured with piercing-cutting tools during the professional practice of the personnel. Data obtained from the study were analyzed using SPSS 17.0 program. According to the results of the research, the reasons for the injuries with piercing and cutting tools were seen to be due to the fact that the operating room workers had to work fast in case of Emergency while taking and delivering piercing and cutting tools during the surgery. In addition, it has been determined that a large number of employees do not report after injury with piercing-cutting tools in the infected for various reasons.
\end{abstract}

Keywords-Operating room, Operating room employee, Surgical instruments, Injury.

\section{INTRODUCTION}

The operating room are the units defined as the heart of a hospital where surgical interventions are applied for diagnosis and treatment. It is important that the operating room environment, health workers, patient and equipment to be used to create the appropriate working area and traffic control is important for the surgeon and nurse to be effective and adequate, patient should be assured (1). The architectural design of the operating rooms, thermal conditions (hot, cold, humidity), lighting, ventilation, radiation control, fire and electrical danger is of great importance for the employees of this unit. In the study of operating room workers, it is emphasized that the working environment and conditions are an important factor in the second place (2). Advances in the field of surgical technology and technique have led to an increase in the need for

Jale Toptepe is with Amasya Public Hospital.

Yıldırım B. Gülhan and Halil Soyal, all are with Okan University Vocational School of Health Services intermediate elements in the surgical field. Thus, the need to improve the quality of the operations and to train more qualified assistant surgical staff has emerged. Operating Room Services; it aims to educate qualified surgical technician who can prepare the surgery room and all surgical materials used in the operating room, as well as assist the surgeon, anesthesiologist and nurse (3). The size of the operating room should be sufficiently large and adequate to allow the surgical team members to wear sterile clothing, the patient to be covered sterile, the surgical team to move comfortably, and the anesthesia team not to interfere with the operation (4).

The health personnel in the operating room are defined as follows, respectively (4-7). Surgeons are the head of the surgical team and are defined as the person who is primarily responsible for the decisions regarding the patient's medical practice and any surgical procedure (2.5). The Assistant is the person who helped the surgeon during the surgery. The assistants hold ekartörleri under the direction of the surgeon to ensure the appearance of the surgical region, the surgical region aspires, sutures are removed $(6,7)$.

\section{MATERIAL AND MethodS}

The aim of this study was to determine the risks and factors affecting the surgical instruments of the health workers in the operating room Department of the State hospitals providing health services in Amasya province. For this purpose, in the first part of the questionnaire questions to be directed to health workers within the scope of the research; 7 questions covering the individual characteristics of the operating room workers (gender, age, marital status, occupation, educational status and working time in the operating room); in the second part, 26 questions including whether employees experienced injuries with piercing and cutting tools during their professional practice, post-injury procedures and methods of protection from injuries were included. The computer was used to analyze the data. The data to be collected for the sub-objectives that are sought for the answers in the general purpose of the research were first processed in the data coding forms. Then, SPSS 17.0 program was used for statistical analysis of the data transferred to the computer. 


\section{FINDINGS}

It is observed that $51.3 \%$ (79) of the operating room workers were male, $42.9 \%$ (66) were male between the ages of 33 and 40 and $74.7 \%$ (115) were married. In terms of education level, $42.2 \%$ (65) of associate degree graduates, $46.1 \%$ (71) of 11 years and over, $31.8 \%$ (49) of them were employed as nurses.

TABLE I:

SOME SOCIO-DEMOGRAPHIC CHARACTERISTICS OF THE PARTICIPANTS

\begin{tabular}{|c|c|c|c|c|}
\hline Variables & & $\mathbf{n}$ & $\%$ & $\mathbf{p}$ \\
\hline \multirow{2}{*}{ Gender } & Female & 75 & 48,7 & \multirow{2}{*}{0,747} \\
\hline & Male & 79 & 51,3 & \\
\hline \multirow{4}{*}{ Age Group } & $\begin{array}{c}\text { Between } 20-26 \\
\text { years }\end{array}$ & 14 & 9,1 & \multirow{4}{*}{0,0001} \\
\hline & $\begin{array}{c}\text { Between } 27-32 \\
\text { years }\end{array}$ & 26 & 16,9 & \\
\hline & $\begin{array}{c}\text { Between } 33-40 \\
\text { years }\end{array}$ & 66 & 42,9 & \\
\hline & 41 and up & 48 & 31,2 & \\
\hline \multirow{2}{*}{ Marital Status } & Married & 115 & 74,7 & \multirow{2}{*}{0,0001} \\
\hline & Single & 39 & 25,3 & \\
\hline \multirow{4}{*}{$\begin{array}{c}\text { Educational } \\
\text { Level }\end{array}$} & Gymnasium & 23 & 14,9 & \multirow{4}{*}{0,0001} \\
\hline & Associate degree & 65 & 42,2 & \\
\hline & Graduate & 27 & 17,5 & \\
\hline & Master & 39 & 25,3 & \\
\hline \multirow{4}{*}{$\begin{array}{c}\text { Service years } \\
\text { in Operating } \\
\text { Room }\end{array}$} & Less than 1 year & 4 & 2,6 & \multirow{4}{*}{0,0001} \\
\hline & Between $1-5$ years & 24 & 15,6 & \\
\hline & $\begin{array}{c}\text { Between } 6-10 \\
\text { years }\end{array}$ & 55 & 35,7 & \\
\hline & 11 years and more & 71 & 46,1 & \\
\hline \multirow{5}{*}{ Proffession } & Nurse & 49 & 31,8 & \multirow{5}{*}{0,0001} \\
\hline & Doctor & 41 & 26,6 & \\
\hline & $\begin{array}{l}\text { Anesthesia } \\
\text { Technician }\end{array}$ & 30 & 19,5 & \\
\hline & Health officer & 25 & 16,2 & \\
\hline & Midwife & 9 & 5,8 & \\
\hline
\end{tabular}

According to the results of the study, $7.8 \%$ (12) of the participants reported to the parent unit, $11.0 \%$ (17) examined the results of the hepatitis $\mathrm{C}$ virus immediately, 49.4\% (76) examined whether the patient was infected with infectious disease, $14.3 \%$ (22) did nothing, $17.5 \%$ (27) applied to other methods. In addition, it was observed that $3.2 \%$ (5) of the results of the methods applied to the penetrating-cutting device to the wound area, 9,1\% (14) of the wound area with alcohol, $54,5 \%$ (84) of the wound area with antiseptic liquid soap, $5,8 \%$ (9) of the wound did nothing, and $27,3 \%$ (42) of the wound area with other methods.

The reasons for not reporting in the operating room personnel after the injury were that $1.9 \%$ (3) of the participants forgot, $14.9 \%$ (23) did not have time, $24.0 \%$ (37) did not think that fame would be beneficial, $22.1 \%$ (34) did not care, and $37.0 \%$ (57) did not report for other reasons. In the present study, the incidence of distrubition of the operating room personnel according to the hours of the operation was $19.5 \%$ (30) of the operating room personnel. per hour, 34.4\% (53)'s second. 3. per hour, 20.1\% (31). 4 of $16.2 \%$ (25) per hour. per hour, $9.7 \%$ (15) of the fifth. they stated that they were distracted by the clock and on.
TABLE II:

POST-INJURY SITUATIONS OF THE PARTICIPANTS WITH CUTTING-DRILLING TOOLS

\begin{tabular}{|c|c|c|}
\hline \multicolumn{3}{|c|}{ Methods applied by puncture-cutting device after injury } \\
\hline Variables & $\mathbf{n}$ & $\%$ \\
\hline I communicated the upper responsables & 12 & 7,8 \\
\hline I'm looking for immediate hepatitis marker results.. & 17 & 11 \\
\hline $\begin{array}{l}\text { I investigated whether there was a contagious disease in } \\
\text { the patient. }\end{array}$ & 76 & 49,4 \\
\hline I have done nothing & 22 & 14,3 \\
\hline Other & 27 & 17,5 \\
\hline \multicolumn{3}{|c|}{ Methods applied to the injured area after drill-cutting tool } \\
\hline I wrecked the wounded area. & 5 & 3,2 \\
\hline I washed the injured area with alcohol. & 14 & 9,1 \\
\hline I washed the injured area with antiseptic liquid soap. & 84 & 54,5 \\
\hline I have done nothing. & 9 & 5,8 \\
\hline Other & 42 & 27,3 \\
\hline \multicolumn{3}{|c|}{$\begin{array}{l}\text { The reasons not reporting after an injury with a } \\
\text { penetrating-cutting instrument }\end{array}$} \\
\hline I have forgotten & 3 & 1,9 \\
\hline I had no time & 23 & 14,9 \\
\hline I did not think it would be useful & 37 & 24 \\
\hline I did not care & 34 & 22,1 \\
\hline Other & 57 & 37 \\
\hline \multicolumn{3}{|l|}{ Distraction of attention according to operation time } \\
\hline 1 hour & 30 & 19,5 \\
\hline 2 hours & 53 & 34,4 \\
\hline 3. hours & 31 & 20,1 \\
\hline 4. hours & 25 & 16,2 \\
\hline 5. hours and more & 15 & 9,7 \\
\hline
\end{tabular}

Those who work in the operating theatre Department $\% 51,3 \%$ male, $\% 48,7 \%$ identified as female, and without statistically significant differences was observed between them $(\mathrm{p}=0,747, \mathrm{p}>0,01)$. Those who do the task in the operating room $\% 42,9 \%$ in the age range of 33 to $40 \%$ $31.2 \%$ were in the age range of 41 and above, it was determined that. Operating theatre of the hospital who participated in the study the variable age of the employees in the Department no statistically significant difference was observed between the distributions in the advanced level $(\mathrm{p}=0,0001, \mathrm{p}<0.01)$.

It was determined that $42.2 \%$ of those who worked in the operating room departments were associate degree graduates. There was a statistically significant difference between the distribution of educational status variables in the operating room departments in the study $(\mathrm{p}=0.0001, \mathrm{p}<0.01)$. It was determined that the associate degree graduates of those who worked in the operating room departments participating in the study were higher than the number of the operating room employees who graduated from high school, undergraduate and graduate.

According to the operating room workers, the most frequent cause of injuries was 20.1 (31) of the Bistro, 26.0 (40) of the injector/Catheter needle, 5.2 (8) of the injector, 32.5 (50) of the suture (suture) material and 16.2 (25) of the injector for other reasons. In addition, $45.5 \%$ (70) of the operating room workers who participated in the study said that the ventilation of the operating room was sufficient, $54.5 \%$ (84) said that the ventilation of the operating room 
was not enough. According to the findings of the operating room staff, $32.5 \%$ (50) of the participants in the study had adequate rest periods in the operating room, while $67.5 \%$ (104) of the patients did not have adequate rest periods in the operating room.

\section{CONCLUSIONS AND RECOMMENDATIONS}

According to the results of the research, the reasons for the injuries with piercing and cutting tools were seen to be due to the fact that the operating room workers had to work fast in case of Emergency while taking and delivering piercing and cutting tools during the surgery. In addition, it has been determined that a large number of employees do not report after injury with piercing-cutting tools in the infected for various reasons.

The working hours of those who work in the operating room departments, which are under intense stress, should be arranged. Those who work in the operating room in the sun during the day can reduce the injury with a piercing tool. Despite the injury of the piercing device, the safety of the operating room needs to be increased. The occupational safety of the operating room employees needs to be kept in the forefront.

\section{REFERENCES}

[1] Sabuncu N, Babadağ K, Taşocak G, Atabek T Principles Of Nursing, (Ed): Selection, H, Eskişehir, 1991.

[2] Mountain GH. Structure of the health sector in Turkey (thesis), Ankara University, Institute of Social Sciences, Master thesis, Ankara, 2006.

[3] Akdemir N, Akkuş Y. "Rehabilitation and nursing", Journal of Nursing school, 2006; 82-91.

[4] Çakmakçı M. (2008). Hospital infections and Hospital design: planning of operating theatres,

http://www.hastaneinfeksiyonlaridergisi.org/managete/fu_folder/200103/html/2001-5-3-172-177.htm, access date: 19.08.2015

[5] Akdur R, Paşal B, Çalışkan D, OCAKTAN me. Public Health, Ankara University Distance Education Publications, Ankara, 2009

[6] Alan Ms. "Principles of ventilation, cleaning and disinfection of the units in the Prevention of Hospital infections", I.Finish. Cerrahpaşa Faculty Of Medicine, Journal Of Continuous Medical Education Activities, 2008; 221-237.

[7] Bed and breakfasts management regulations, www.saglik.gov.tr/hm/dosya/1-

$66763 / \mathrm{h} /$ yatakli $\& \mathrm{CD}=1 \& \mathrm{HL}=\mathrm{TR} \& \mathrm{CT}=\mathrm{clnk} \& \mathrm{GL}=\mathrm{TR}$ access date: 26.08.2016. 